\title{
Study of the Tableting Properties of MCR, a Newly Coprocessed Cellulose-based Direct Compression Excipient
}

\author{
Yeni Koproses Selüloz Bazlı Doğrudan Basım Yardımcı Maddesi Olan \\ MCR'nin Tabletleme Özelliklerinin İncelenmesi
}

\author{
D Salah ALY* \\ Al Jouf University, Pharmacy College, Department of Pharmaceutics, Sekake, Saudi Arabia \\ Present Address: Chemical Industries Development, Cid, Assiut Branch, Assiut, Egypt
}

\begin{abstract}
Objectives: In this work, the aim was to coprocess and evaluate a new cellulose-based direct compression tableting excipient (MCR) of improved functionalities by granulation and slugging from locally extracted microcrystalline cellulose and regenerated cellulose (CRC).

Materials and Methods: Model tablet formulations of metronidazole (MZ) as a model of nonfreely flowing and directly incompressible active pharmaceutical ingredient were designed to study the tableting properties of MCR.

Results: The results showed that the optimum concentration of CRC needed to produce excipient of accepted flow properties and high compression characteristics was $20 \% \mathrm{w} / \mathrm{w}$. MCR performed better than the parent components either singly or in a simple binary mixture. MZ tablets of enhanced mechanical properties and fast disintegrating and dissolving rates were compressed from MCR. The crushing strength (H) and the disintegration rate constant $\left(\mathrm{k}_{\mathrm{d}}\right)$ increased from 3.76 to $11.08 \mathrm{~kg}$ and from 0.92 to $13.1 \times 10^{-3} \mathrm{~s}^{-1}$ for the tablets made with $50 \% \mathrm{w} / \mathrm{w} \mathrm{MCR}$, respectively. Conclusion: Both the $\mathrm{H}$ and $\mathrm{k}_{d}$ values of a given $\mathrm{MZ}$ tablet batch were found to be functions of the total number of bonding sites ( $\alpha$ ) available in the excipient in the given batch. MCR was unfortunately sensitive to magnesium stearate. The obtained result revealed that MCR is a successful complementary direct compression excipient.
\end{abstract}

Key words: Microcrystalline cellulose, regenerated cellulose, MCR co-processing, MCR tableting properties

öz

Amaç: Bu çalışmada, lokal olarak ekstrakte edilmiş mikrokristal selülozdan ve rejenere selülozdan (CRC) granülasyon ve slugging ile gelişmiş işlevsellikli yeni selüloz bazlı doğrudan basım tabletleme yardımcı maddesini (MCR) koprosesini ve değerlendirmeyi amaçladık.

Gereç ve Yöntemler: Serbest akmayan ve dolaylı olarak sıkıştırılabilir bir aktif farmasötik bileşen modeli olarak metronidazolün (MZ) model tablet formülasyonları, MCR'nin tabletleme özelliklerini incelemek için tasarlanmıştır.

Bulgular: Kabul edilen akış özellikleri ve yüksek sıkıştırma özelliklerindeki yardımcı maddeyi üretmek için gereken optimum CRC konsantrasyonunun, \%20 (a/a) olduğunu göstermiştir. MCR, bileşenlerin tek başına veya basit bir ikili karışım içerisinde olmasından daha iyi performans göstermiştir. MCR ile geliștirilmiș mekanik özelliklere ve hızlı dağılma ve çözünme hızlarına sahip olan MZ tabletleri basılmıștır.

Sonuç: Kırma dayanımı $(H)$ ve dağılma hız sabiti $\left(k_{d}\right)$, \%50 a/a MCR ile yapılan tabletler için sırasıyla 3.76 'dan 11.08 kg'a ve 0.92 'den $13.1 \times 10^{-3} \mathrm{~s}^{-1} \mathrm{e}$ yükselmiştir. Belirli bir MZ tablet partisinin hem $\mathrm{H}$ hem de $\mathrm{k}_{d}^{\prime}$ sinin, verilen partideki yardımcı maddenin içinde mevcut olan toplam bağlanma bölgesi sayısının $(\alpha)$ fonksiyonu olduğu bulunmuştur. MCR ne yazık ki magnezyum stearata karşı duyarlıydı. Elde edilen sonuç, MCR'nin başarılı bir tamamlayıcı doğrudan basım yardımcı maddesi olduğunu ortaya koymuştur.

Anahtar kelimeler: Mikrokristal selüloz, rejenere selüloz, MCR koproses, MCR tabletleme özelliği

*Correspondence: E-mail: sasalytout@hotmail.com, Phone: 00201026470816 ORCID-ID: orcid.org/0000-0003-3108-6209

Received: 14.09.2017, Accepted: 08.02.2018

Turk J Pharm Sci, Published by Galenos Publishing House. 


\section{INTRODUCTION}

The coprocessing technique has been utilized to develop excipients of improved and/or desired functionalities. The technique is defined as the concept of two or more excipients interacting physically at the subparticle level to provide a synergy of functionality and improvements as well as masking the undesirable properties of individual excipients.' It provides a broad platform for the manipulation of excipient functionality or particle engineering of two or more existing excipients. ${ }^{2,3}$ Silicified microcrystalline cellulose (MCC) (Prosolve), Cellactose, and Avicel CE-15 are commercially available coprocessed excipients that have improved flow and consolidation properties. ${ }^{4-10}$ Controlling particle size and particle-size distribution as coprocessing means were used to produce excipients of improved flow with no need to add glidants. ${ }^{5-7}$ However, cases of some coprocessed powders with enhanced mechanical properties but having similar particlesize distribution of the parent powders were reported. ${ }^{4-10}$

One of the major limitations challenging the coprocessing technique is the fixed ratio of the excipients in a coprocessed mixture, which may not be an optimum choice for the active ingredient(s) and the dose for a formulation under development."

MCC tableting properties are close to optimal. The excipient has high degrees of compressibility and compactibility, and high dilution potential. However, the bad flow properties and the sensitivity to magnesium stearate (MS) are the main drawbacks of this excipient. ${ }^{12}$ Cellulose regenerated (RC) from microfibril showed high physicochemical and tableting properties. ${ }^{13}$ Ahmad $^{14}$ reported that RC has glidant activity. Rojas et al. ${ }^{15}$ found that RC has strong disintegration activity. Due to its large specific surface area, RC was successfully employed with olive oil to produce Dis-Lub-Tout, a newly coprocessed tablet excipient of bifunctional activity. 16,17

Metronidazole (MZ) is an antimicrobial agent effective against anaerobic bacteria and protozoa. It is primarily used to treat bacterial vaginosis, pelvic inflammatory disease, wounds, intraabdominal infections, trichomoniasis, and infections caused by susceptible anaerobic organisms. Tablets are the commonly used dosage form of this drug. ${ }^{18}$ Trials were conducted to coprocess excipients to manufacture direct compression MZ tablets. ${ }^{19,20}$

Our objective in this work was to coprocess and evaluate the tableting properties of cellulose-based direct compression tableting excipient (MCR), a new cellulose-based tableted excipient produced from the granules of colloidal microcrystalline cellulose (CMCC)/regenerated cellulose (CRC) slugs. CMCC was locally extracted from the dried leaves and hollow stems of the common reed plant [Phragmites australis (Gramineae)] and was used to prepare CRC. Metronidazole, a model of nonfreely flowing incompressible active pharmaceutical ingredient (API) powder, was employed to evaluate the tableting properties of MCR.

\section{MATERIALS AND METHODS}

\section{Materials}

Dried leaves and hollow stems of the common reed plant were collected from different areas near water resources and sewages in the town of Assiut (upper Egypt) at harvest time (March-June). Analytical-grade chemicals, namely absolute ethanol and sodium hydroxide pellets given by Krishna Chemicals, Mumbai-40078, Maharashtra, and 98\% sulfuric acid obtained from Scharalab, S.L., Gato Prez, Spain, were used in this investigation. Metronidazole (Provizer Pharma, India), a model of nonfreely flowing incompressible API, and MS, the commonly used tablet lubricant (Scharalab, S.L., Gato Prez, Spain), were employed in this investigation.

\section{Methods}

\section{CMCC and CRC processing}

The collected plant material was thoroughly examined and the decayed parts were discarded. The selected parts were thoroughly washed, dried, and ground using a suitable grinder. A 500-g sample of the powdered plant material was boiled in $2 \%$ sulfuric acid for $2 \mathrm{~h}$ to destroy the lignin content in order to separate the cellulose fibers. The acid and the acid soluble materials were filtered out and the collected solid material was washed to remove the acid, neutralized, and boiled in $12 \%$ sodium hydroxide solution for $4 \mathrm{~h}$ to completely get rid of the lignin. The solid material was thoroughly washed to remove the alkali, neutralized, and subjected to acid hydrolysis by boiling in $3 \mathrm{~L}$ of $10 \%$ sulfuric acid solution for $3 \mathrm{~h}$ to produce CMCC. The yield was thoroughly washed to remove the acid, neutralized, and bleached by boiling in $3 \mathrm{~L}$ of $6 \%$ sodium hypochlorite for $2 \mathrm{~h}$. The CMCC was thoroughly washed with distilled water, neutralized, dried, pulverized, and stored in a screw-capped brown powder bottle until use. A 100-g sample of CMCC was suspended in $300 \mathrm{~mL}$ of $20 \%$ sodium hydroxide solution. The suspension was frozen at $-28^{\circ} \mathrm{C}$ for $12 \mathrm{~h}$ to dissolve the cellulose. The frozen cellulose solution was kept at room temperature $\left(25 \pm 2^{\circ} \mathrm{C}\right)$ for $18 \mathrm{~h}$. CRC precipitated with $1 \mathrm{~N}$ sulfuric acid solution was thoroughly washed with distilled water, neutralized, dried, pulverized, and stored at room temperature $\left(25 \pm 2^{\circ} \mathrm{C}\right)$ in screwcapped brown powder bottles until use.

\section{Infrared characterization of cellulose powders}

The infrared (IR) spectra of authentic MCC sample and samples of CMCC and CRC powders were run using the technique described by Rojas et al. ${ }^{21}$ In this technique, $1 \mathrm{mg}$ of a given sample was mixed with $100 \mathrm{mg}$ of $\mathrm{KBr}$ in an agate mortar. Pellets of this mixture were prepared on a portable press (CrushIR Digital Hydraulic Press 161-1900, PIKE, Madison, WI, USA) at a dwell time of $5 \mathrm{~min}$ and at a force of $4540 \mathrm{~kg}$. The infrared spectra were run between 650 and $4000 \mathrm{~cm}^{-1}$ using a PerkinElmer IR spectrometer (Spectrum BX, PerkinElmer, San Jose, CA, USA) equipped with the software Ommic (Nicolet Corp., Madison, WI, USA). The resolution and interval length were 16 and $2 \mathrm{~cm}^{-1}$, respectively, and the number of scans employed was $16 \mathrm{~cm}^{-1}$. 


\section{Physical properties of cellulose and MZ powders}

\section{Particle shape and effective mean particle diameter}

The shapes of CMCC and CRC particles were characterized by scanning electron microscopy (SEM) (BM-180, Bo-eco, GmbH, Frankfurt, Germany) attached to a digital camera (S8000fd, Fujifilm Corp., Japan). A suitable volume of the given powder sample was mounted in the specimen stub of the SEM for microphotographing (no sputtering was noticed). The effective mean diameters of CMCC and MZ particles were determined by the sieving technique using a set of stainless steel sieves (Fritsch, GmbH, FRG) arranged in descending order as described earlier. ${ }^{16}$ The effective mean diameter of CRC particles was determined using a size analyzer (Brookhaven Instruments Corp., Holtsville, NY, USA) equipped with default particle sizing software (ver. 3.74). A sample of dilute CRC/water suspension was used for the test. The refractive index of the sample was 1.33 , while the beam angle and the wavelength were $90^{\circ}$ and 678 $\mathrm{nm}$, respectively.

\section{Flow properties, density, and moisture content determinations} of powders

The funnel technique was employed to determine the volumetric flow rates and repose angles of the powders under investigation. The apparent density, o, of a given powder was determined using the liquid displacement technique. The bulk, $\varrho_{B}$, and tap, $\varrho_{T}$, densities and packing fraction, of, were determined using earlier reported techniques. ${ }^{16}$ The mean of five determinations of each experiment was calculated and taken as the determined value. The moisture content (dry weight basis) was determined by drying technique as described earlier.16

\section{Moisture sorption isotherm study}

The moisture sorption isotherm exhibited by MCR was studied and compared with that of the parent components. For the test, accurately weighed $1-g$ samples of MCR CRC, and CMCC were stored on a shelf in ambient conditions $\left[25 \pm 2^{\circ} \mathrm{C}\right.$ - relative humidity $(\mathrm{RH}) 45 \pm 2 \%]$ and at $40^{\circ} \mathrm{C}-\mathrm{RH} 75 \%$. The $\mathrm{RH} \%$ conditions were achieved using a saturated solution of sodium chloride. A Gallenkamp humidity oven (Gallenkamp, London, United Kingdom) was employed for the test. At a predetermined time interval, a sample of a stored powder was evaluated for the amount of adsorbed moisture (dry weight basis).

\section{Swelling index and hydration capacity determinations}

The swelling index (SI) of a given cellulose powder was determined as follows: ${ }^{16}$ an accurately weighed 1-g sample of the given cellulose powder was suspended in $25 \mathrm{~mL}$ of distilled water and vigorously shaken at 10-min time intervals for $1 \mathrm{~h}$. The suspension was equilibrated for $24 \mathrm{~h}$ and the volume occupied by the powder under the test was precisely determined. SI was calculated from: $S I=v-v^{0} / v^{0} \times 100$, where $v$ and $v^{0}$ stand for the volumes of the test powder sample before and after the test, respectively. The mean of such 5 determinations was taken as the $\mathrm{SI}$ of the given powder. The hydration capacity $(\mathrm{HC})$ of a given cellulose powder was measured as follows: a 2-g sample of a given powder was suspended in $10 \mathrm{~mL}$ of distilled water in a centrifuge tube and shaken intermittently for $2 \mathrm{~h}$. The tube was left to stand for $30 \mathrm{~min}$ and centrifuged at $3000 \mathrm{rpm}$ for $10 \mathrm{~min}$. $\mathrm{HC}$ was calculated from the weight $(w)$ of the powder before the test as $\mathrm{HC}=\mathrm{w}-2 / 2 \times 100$ as reported earlier. ${ }^{16}$ The mean of 5 such determinations was taken as the $\mathrm{HC}$ of the given powder

\section{MCR coprocessing}

Binary mixtures of $\mathrm{CMCC} / \mathrm{CRC}$ containing varying portions of CRC were prepared using a laboratory assembled $0.75-\mathrm{kg}$ capacity drum mixer. The preliminary tests carried out showed that the optimum concentration of CRC needed to produce a mixture of improved flow properties (flow rate and repose angle) was $20 \% \mathrm{w} / \mathrm{w}$ ( 1 part CRC to 4 parts CMCC). A batch of $500 \mathrm{~g}$ of this physical mixture was prepared and employed to coprocess MCR as follows. The mixture was placed into a porcelain mortar of suitable capacity and kneaded with a sufficient volume $(400 \mathrm{~mL})$ of absolute ethanol. The damp mass was forced through a 350- $\mu \mathrm{m}$-mesh sieve and the resulting granules were dried at $50^{\circ} \mathrm{C}$ for $6 \mathrm{~h}$ using a Binder oven (FRG). The granules were placed on a tray and put into the oven. The obtained dried granules were equilibrated at room conditions for $24 \mathrm{~h}$. Although the fourier-transform infrared spectroscopy technique to test for the residual alcohol in pharmaceutical solids is limited by the high detection limit (above 100 ppm), it was decided to employ it using the above-mentioned method and equipment to test for residual alcohol in the prepared granules since the allowed limit for residual ethanol in pharmaceutical solids is high (5000 ppm). ${ }^{22}$ The IR spectrum run showed that the produced granules were alcohol-free. The produced granules were compressed into large slugs using a single punch tableting machine (F3, Manesty Machines Ltd., Liverpool, UK). The machine settings were adjusted to produce slugs of 5-g mean weight and of the highest tensile strength that could be achieved. The machine was manually run and the surfaces of the punches were frequently cleaned of sticky powder. The produced slugs were crushed using a laboratory oscillating granulator and sifted through a 90- $\mu \mathrm{m}$-mesh sieve. The obtained MCR powder was stored at room temperature $\left(25 \pm 2^{\circ} \mathrm{C}\right)$ in a screw-capped wide mouth brown powder bottle until use.

\section{Characterization of MCR}

The flow rate, repose angle, packing fraction, of, and density (apparent, bulk and tap) of MCR were determined using the above-mentioned techniques. The moisture content, swelling index, and hydration capacity determinations were also carried out employing the above-mentioned methods. ${ }^{16}$ The mean of 5 determinations of each experiment was calculated and taken as the determined value.

\section{Formulation, compression, and evaluation of $M Z$ tablets}

A simple mixing technique was adopted to prepare $M Z$ tablets. Tablets batches formulated with 20\%,30\%, 50\%, and $75 \% \mathrm{w} / \mathrm{w}$ of a given excipient were prepared. Lubrication was carried out just before compression. Tablets were compressed using a Manesty single punch tableting machine fitted to flat faced punches adopting the modified compression technique. ${ }^{17}$ The machine was adjusted to compress tablets of $250 \pm 0.05 \mathrm{mg}$ 
mean weight, $9.0 \pm 0.02 \mathrm{~mm}$ mean diameter, and of the highest crushing strength, $\mathrm{H}$, and lowest friability, F, levels that could be achieved from the batch formulated with $75 \% \mathrm{w} / \mathrm{w}$ (the highest concentration) of a given excipient. The machine settings were kept constant throughout compressing the rest of the batches formulated with the lower concentration of the given excipient. Altogether 1000 tablets were compressed from each batch. The machine settings were readjusted whenever formulations of a new excipient were compressed. The produced tablets were evaluated for uniformity of weight and thickness, mechanical properties, (H, F, and porosity, E), and disintegration times (Dt).

\section{Determination of $H, \mathcal{E}$, and $F$ of $M Z$ tablets}

A digital recording hardness tester, Erweka TBH-28 (Erweka, Darmstadt, Germany), was used to determine the mean crushing strength of a given $M Z$ tablet batch. For the test, a sample of 10 tablets was randomly collected from a given batch. The tablets were individually tested for crushing strength and the mean was calculated and taken as the crushing strength of the given batch. $\varepsilon$ of a given tablet batch was calculated from the relation $\varepsilon=\left(v_{t}-v_{0}\right) / v_{t}$, where $v_{t}$ and $v_{0}$ equal the tablet volume and the true volume(s) of the powder (s) in the given tablet batch. The mean of five calculations was considered the porosity of the given tablet batch. F of a MZ tablet batch was determined using a Roche friabilator (Erweka, Darmstadt, Germany). A sample of 20 tablets randomly collected from the given batch was brushed free of adhering dust and precisely weighed and placed into the friabilator drum. The apparatus was adjusted to revolve at $25 \mathrm{rpm}$ for $4 \mathrm{~min}$. At the end of the test, the tablets were rebrushed and precisely reweighed. The percent loss in weight was calculated as F of the tablets. The mean of such five determinations was used as $F$ of the tested $\mathrm{MZ}$ tablet batch.

\section{Determination of Dt and $k_{d}$ of tablets}

Neutral buffer solution of $\mathrm{pH} 7.2$ was employed to carry out the disintegration and dissolution rate determination tests. This was to exclude the effect of $\mathrm{pH}$ of the medium on the disintegration and dissolution rates.

\section{Determination of Dt of tablets}

A USP disintegration test apparatus (ZT 220, Erweka, Darmstadt, Germany) was employed to determine the disintegration times of the compressed tablets. A sample of 6 tablets randomly selected from a given MZ batch was used in this investigation. Each tablet was accurately weighed and placed into a disintegration tube of the apparatus. The time when the fragments of the tested tablet completely passed through the screen mesh at the base of the disintegration tube was recorded as the Dt. The mean of such 10 determinations was calculated as the Dt of a given MZ batch.

\section{Study of dissolution behavior of MZ tablets}

A rotating basket USP dissolution rate test apparatus (model DT$D$, Erweka, Germany) was employed to determine the dissolution rate of $\mathrm{MZ}$ tablets in $900 \mathrm{~mL}$ of 7.2 buffer solution. All the USP requirements for dissolution rate test were kept constant. The test was carried out at $37 \pm 0.5^{\circ} \mathrm{C}$. A sample of 6 tablets randomly collected from a given batch was employed to carry out the test. For the test, one tablet was precisely weighed and placed into the basket of the apparatus. The revolution of the basket was adjusted to $100 \mathrm{rpm}$. At a predetermined time interval accommodated with the disintegration time of the batch under the test, a 5-mL aliquot sample was withdrawn from the dissolution chamber and was immediately substituted by an equal volume of freshly prepared dissolution medium maintained at $37 \pm 0.5^{\circ} \mathrm{C}$. The amount of $\mathrm{MZ}$ in the withdrawn sample was determined spectrophotometrically at $340 \mathrm{~nm}$ with reference to a calibration curve constructed using a pure MZ sample as used in the formulation. The mean of such 6 determinations was taken as a point on the dissolution curve.

\section{Study of MCR sensitivity against MS}

The effects of lubrication with $1.0 \%, 1.5 \%$, and $3 \% \mathrm{w} / \mathrm{w}$ of MS on the $\mathrm{H}, \mathrm{F}$, and $\mathrm{Dt}$ values of the $\mathrm{MZ}$ tablet batch formulated with $75 \% \mathrm{w} / \mathrm{w}$ of MCR were studied.

\section{RESULTS}

\section{IR characterization of CMCC and CRC}

The IR spectra of MCC and CRC powders given in Figure 1 show the following characteristic vibration peaks of cellulose: $3445 /$ $\mathrm{cm}$ corresponding to intramolecular $\mathrm{OH}$ stretching, including hydrogen bonds; $2898 / \mathrm{cm}$ due to $\mathrm{CH}$ and $\mathrm{CH}_{2}$ stretching; 1650 / $\mathrm{cm}$ corresponding to $\mathrm{OH}$ from absorbed water; $1430 / \mathrm{cm}$ due to $\mathrm{CH}_{2}$ symmetric bending; $1375 / \mathrm{cm}$ due to $\mathrm{CH}$ bending; $1330 / \mathrm{cm}$ due to $\mathrm{OH}$ in-plane bending; $1161 / \mathrm{cm}$ due to $\mathrm{C}-\mathrm{O}-\mathrm{C}$ asymmetric stretching ( $\beta$-glucosidic linkage); $1061 / \mathrm{cm}$ due to $\mathrm{C}-\mathrm{O} / \mathrm{C}-\mathrm{C}$ stretching; and $898 / \mathrm{cm}$ corresponding to the asymmetric (rocking) $C-1$ ( $\beta$-glycosidic linkage) out-of-plane stretching vibrations. No new peaks were seen in the spectra, suggesting that CMCC and CRC are chemically similar to microcrystalline cellulose.

\section{Physical properties of cellulose and MZ powders}

Figure 2 shows that $\mathrm{CMCC}$ and $\mathrm{CRC}$ particles were morphologically similar. They were elongated and amorphous particles. Table 1

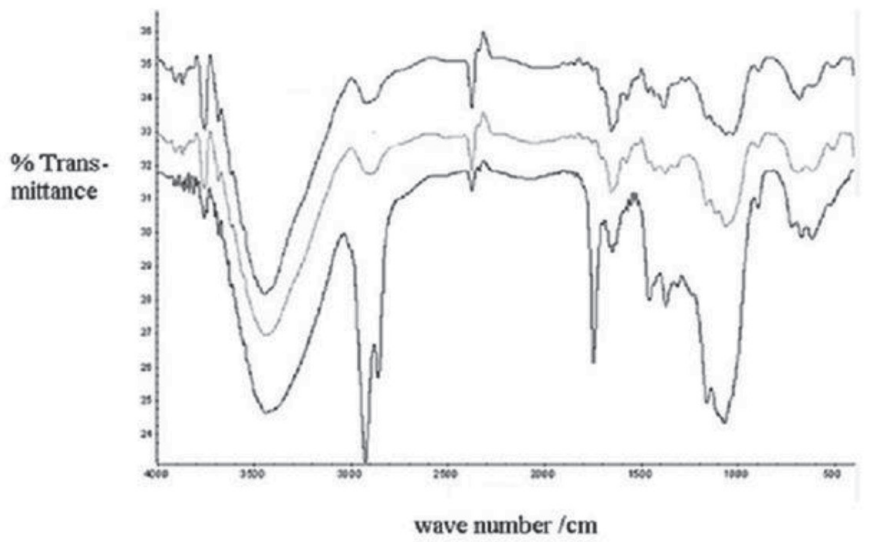

Figure 1. IR spectra for MCC (upper curve), CRC (middle curve), and CMCC (lower curve)

MCC: Microcrystalline cellulose, CRC: Regenerated cellulose, CMCC: Colloidal microcrystalline cellulose, IR: Infrared 
shows that their effective mean particle diameters were 90 and $3 \mu \mathrm{m}$, respectively. Such elongated particles have a tendency to intermesh and create internal resistance against the flow of the powder.12

Table 1 also shows that the moisture contents and SI and HC values of the studied powders were high. Figure 3 shows that the investigated excipients exhibited more or less equal moisture sorption isotherm patterns.

Physical properties of $M Z$ tablets

Uniformity of $M Z$ tablets

The data in Table 2 show that more uniform MZ tablets were compressed with CRC followed by MCR and CMCC, in that order. The uniformity generally increased (estimated by the decrease in $\% \mathrm{CV}$ ) as the concentration of the excipient in an examined tablet batch increased. Powder metallurgy (PM) produced nonuniform tablets due to the segregation observed during compression.

\section{Mechanical properties of $M Z$ tablets}

\section{Compressibility and compactibility of excipients}

The yield value obtained from the Heckel ${ }^{23}$ plot and the energy consumption during compression determined from the forcedisplacement plot $^{24}$ are usually parameters used to measure powders' compressibility. In this investigation since a given tablet
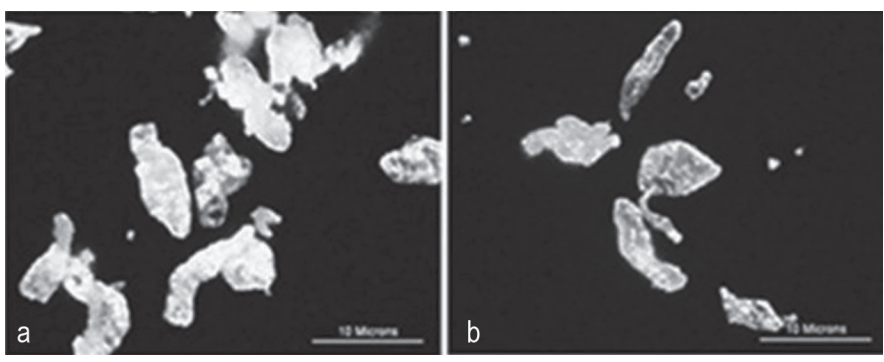

Figure 2. Microphotographs for a) CMCC, and b) CRC

CMCC: Colloidal microcrystalline cellulose, CRC: Regenerated cellulose formulation was compressed under confined machine settings, it follows that the number of sites available for bonding in a given concentration of an excipient in a formulation is the sole working parameter. In other words, the mechanical properties of the excipient in the given formulation are excipient concentration dependent factors. An excipient concentration-displacement plot was constructed (see Figure 4a) and the area under the curve (AUC) was taken as a parameter indicative of the compressibility of a studied excipient. The compressibility index, $\mathrm{k}_{\varepsilon^{\prime}}$ of an excipient in a given formulation was calculated from the relation;

\section{$\mathcal{E}=\varepsilon^{\circ}$ exp. $-\mathrm{k}_{\varepsilon} \mathrm{C}$}

where $\varepsilon$ and $\varepsilon^{\circ}$ stand for the porosity fractions for compacts made from a given excipient and the lubricated drug only (control tablets batch) (see Figure 4b), respectively. On the other hand, Figure $4 \mathrm{c}$ was constructed to calculate the compactibility index, $\mathrm{k}_{\mathrm{p}}$, of the given excipient. It was calculated from the relation;

$$
\mathrm{H}=\mathrm{H}^{0} \exp . \mathrm{k}_{\mathrm{p}} \mathrm{C}
$$

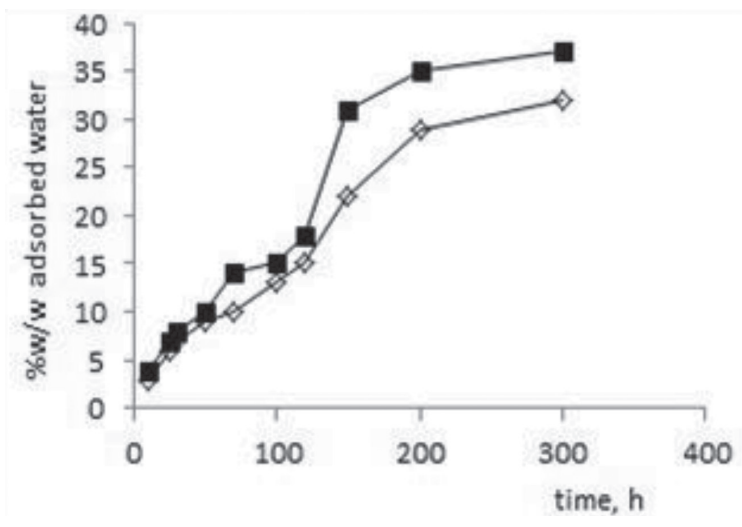

Figure 3. Moisture sorption isotherm exhibited by MCR stored at $\mathrm{O}$, ambient condition and at $\square, 40^{\circ} \mathrm{C}-75 \% \mathrm{RH}$

MCR: Cellulose-based direct compression tableting excipient, $\mathrm{RH}$ : Relative humidity

Table 1. Physical properties of metronidazole and the investigated cellulose powders

\begin{tabular}{|c|c|c|c|c|c|c|c|c|c|c|c|c|c|}
\hline $\begin{array}{l}\text { Drug and } \\
\text { excipient } \\
\text { used }\end{array}$ & $\begin{array}{l}\text { Mean } \\
\text { part } \\
\text { diam } \\
\mu \mathrm{m}\end{array}$ & $\begin{array}{l}\text { Flow } \\
\text { rate } \mathrm{g} \\
\mathrm{s}^{-1} \pm \\
\mathrm{SD}\end{array}$ & $\begin{array}{l}\text { Repose } \\
\text { angle } \\
\text { degree } \pm \\
\text { SD }\end{array}$ & $\begin{array}{l}\text { Density } \\
\text { App } \pm \\
\text { SD }\end{array}$ & $\begin{array}{l}\text { Bulk } \pm \\
\text { SD }\end{array}$ & $\begin{array}{l}\text { Tap } \pm \\
\text { SD }\end{array}$ & $\begin{array}{l}\text { Moist } \\
\text { contact } \\
\% w / w \pm \\
\text { SD }\end{array}$ & $\begin{array}{l}\text { Packing } \\
\text { fraction } \\
\text { of } \% \\
\text { calculated }\end{array}$ & $\begin{array}{l}\text { Compressibility } \\
\text { index \% }\end{array}$ & $\begin{array}{l}\text { Haussner } \\
\text { ratio }(\mathrm{h})\end{array}$ & $\begin{array}{l}\text { Surface } \\
\text { area } \\
\mathrm{m}^{2} \mathrm{~g}^{-1} \times 10^{-2} \\
\text { calculated }\end{array}$ & $\begin{array}{l}\text { Hydration } \\
\text { capacity } \\
\text { g/g } \pm S D\end{array}$ & $\begin{array}{l}\text { Swell } \\
\text { index } \\
\text { g/g } \pm \\
\text { SD }\end{array}$ \\
\hline$M Z$ & 90 & $\begin{array}{l}0.11 \\
(0.03) \\
\end{array}$ & $40(2.11)$ & $\begin{array}{l}1.5 \\
(0.34) \\
\end{array}$ & $\begin{array}{l}0.90 \\
(0.11) \\
\end{array}$ & $\begin{array}{l}1.30 \\
(0.31) \\
\end{array}$ & $\begin{array}{l}3.50 \\
(0.34) \\
\end{array}$ & 59 & 31 & 1.44 & 6.5 & - & - \\
\hline CMCC & 90 & $\begin{array}{l}0.21 \\
(0.10) \\
\end{array}$ & $\begin{array}{l}42 \\
(4.30) \\
\end{array}$ & $\begin{array}{l}1.50 \\
(0.76) \\
\end{array}$ & $\begin{array}{l}0.91 \\
(0.18) \\
\end{array}$ & $\begin{array}{l}1.32 \\
(0.52) \\
\end{array}$ & $\begin{array}{l}4.76 \\
(0.19) \\
\end{array}$ & 61 & 31 & 1.45 & 8.2 & $\begin{array}{l}2.31 \\
(0.41) \\
\end{array}$ & $\begin{array}{l}1.50 \\
(0.33) \\
\end{array}$ \\
\hline CRC & 3 & $\begin{array}{l}1.20 \\
(0.05)\end{array}$ & $\begin{array}{l}38 \\
(6.70)\end{array}$ & $\begin{array}{l}1.52 \\
(0.32)\end{array}$ & $\begin{array}{l}0.28 \\
(0.27)\end{array}$ & $\begin{array}{l}0.41 \\
(0.13)\end{array}$ & $\begin{array}{l}6.4 \\
(0.08)\end{array}$ & 18 & 32 & 1.46 & 132.0 & $\begin{array}{l}2.87 \\
(0.65)\end{array}$ & $\begin{array}{l}1.75 \\
(0.53)\end{array}$ \\
\hline MCR & - & $\begin{array}{l}0.94 \\
(0.09)\end{array}$ & $\begin{array}{l}38 \\
(3.92)\end{array}$ & $\begin{array}{l}1.62 \\
(0.18)\end{array}$ & $\begin{array}{l}0.78 \\
(0.20)\end{array}$ & $\begin{array}{l}1.25 \\
(0.16)\end{array}$ & $\begin{array}{l}5.38 \\
(0.54)\end{array}$ & 48 & 38 & 1.60 & - & $\begin{array}{l}2.67 \\
(0.34)\end{array}$ & $\begin{array}{l}1.73 \\
(0.22)\end{array}$ \\
\hline
\end{tabular}

SD: Standard deviation, MZ: Metronidazole, CMCC: Colloidal microcrystalline cellulose, CRC: Regenerated cellulose, MCR: Cellulose-based direct compression tableting excipient, PM: Powder metallurgy 
Table 2. Physical properties of metronidazole tablets compressed directly with increasing concentrations of the named cellulose excipients

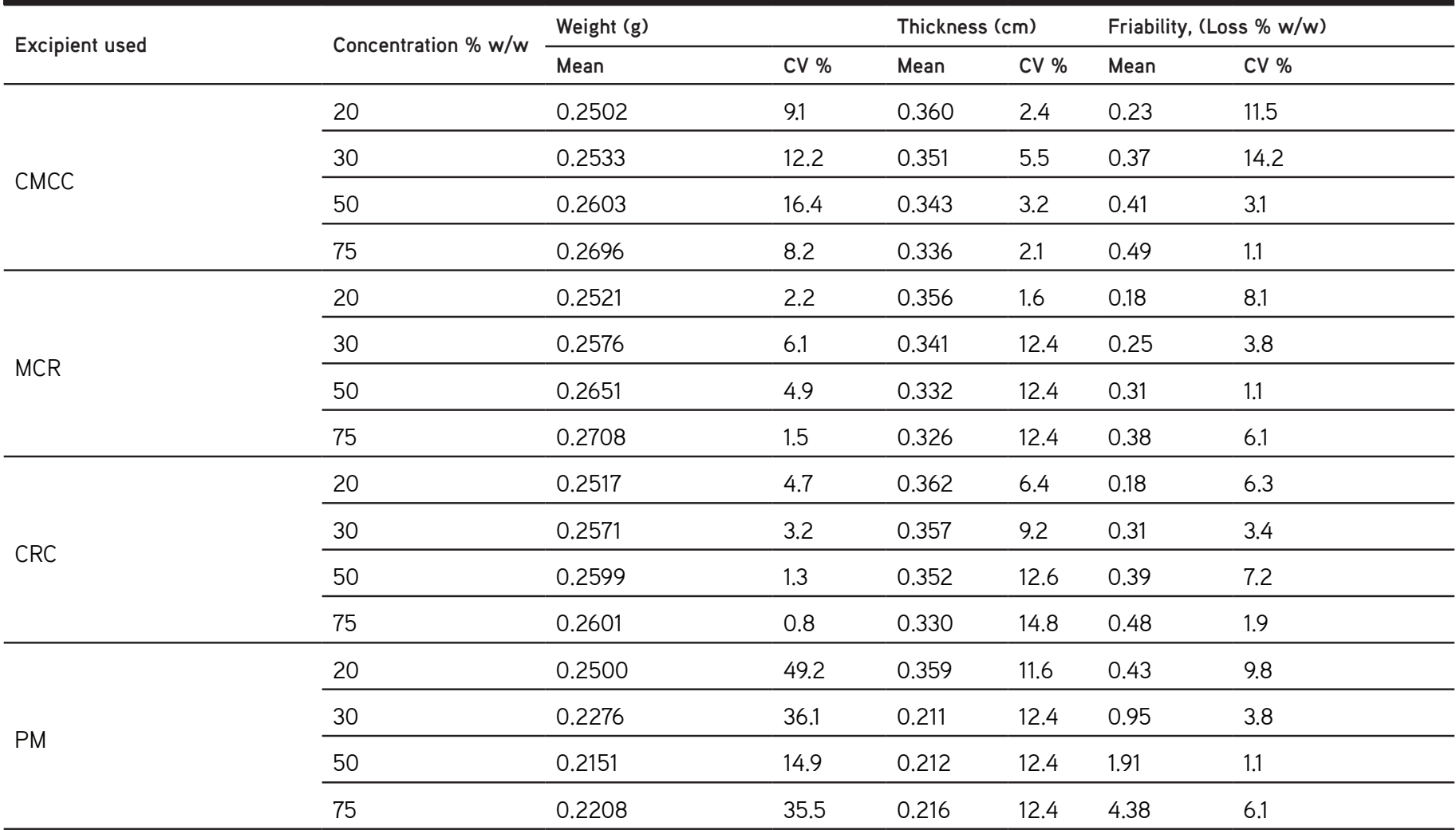

CMCC: Colloidal microcrystalline cellulose, MCR: Cellulose-based direct compression tableting excipient, CRC: Regenerated cellulose, PM: Powder metallurgy
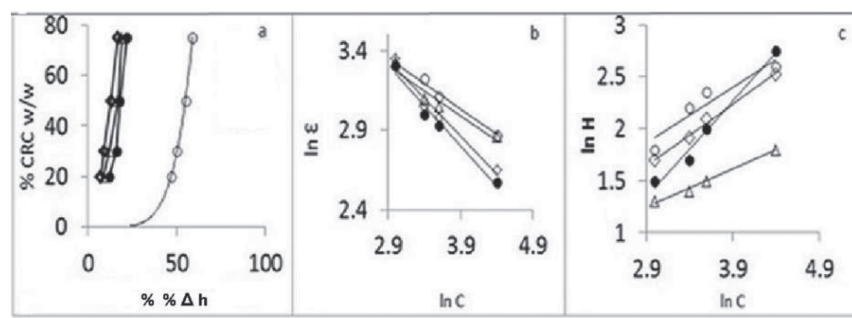

Figure 4. a) The reduction in tablet height as a function of $\% \mathrm{MCR}$ concentration, C; b) In $\varepsilon$ vs C; and C), In H vs C. Key: $\diamond$, MCC; $\triangle$, CMCC; $\bullet$ $\mathrm{CRC}$, and $\mathrm{O}, \mathrm{MCR}$

MCR: Cellulose-based direct compression tableting excipient, MCC: Microcrystalline cellulose, CMCC: Colloidal microcrystalline cellulose, CRC: Regenerated cellulose

where $\mathrm{H}$ and $\mathrm{H}^{\circ}$ represent the crushing strengths of the batches made with the given excipient and the control tablets batch, respectively. The data given in Table 3 show that more compressed formulation was produced by MCR, followed by CRC, CMCC, and PM, in that order.

\section{Disintegration and dissolution behaviors of $M Z$ tablets}

Figure 5 shows that the disintegration rate constant, $k_{d}$, generally decreased as the excipient concentration, $\mathrm{C}$, increased in a given tablet batch and the relation;

\section{$\mathrm{k}_{\mathrm{d}}=\mathrm{k}_{\mathrm{d}}{ }^{0} \exp . x \mathrm{C}$}

where $x$ is the disintegration activity of the excipient in a given formulation, worked. The constants $k_{d}$ and $k_{d}{ }^{\circ}$ stand for the disintegration rate constants of the batches made with a given excipient and the control tablets batch, respectively. The data

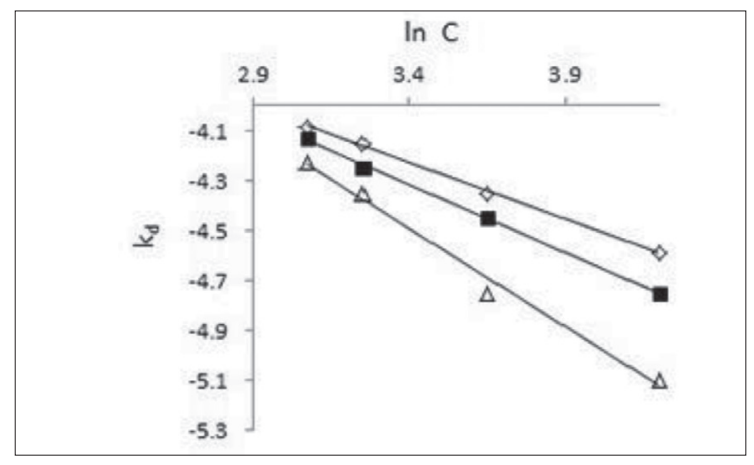

Figure 5. $\ln \mathrm{k}_{\mathrm{d}}$ vs $\ln \mathrm{C}$ for the tested $\mathrm{MZ}$ tablets MZ: Metronidazole

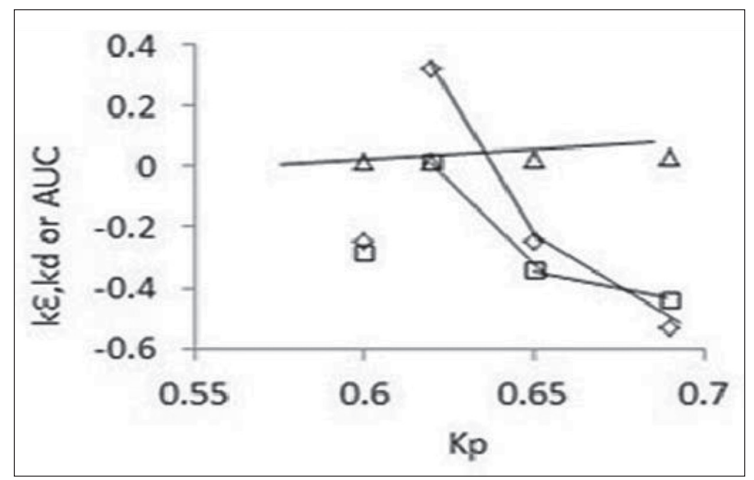

Figure 6. $k \varepsilon, k_{d}$, or $A U C$ as functions of $k p$ for the tested $M Z$ tablets MZ: Metronidazole, AUC: Area under the curve 
Table 3. Some parameters determined for the tested cellulose excipients using the mathematical expressions in the text

\begin{tabular}{lllll} 
Excipients used & AUC $\mathrm{cm}^{2} \times 10^{-2}$ & $k_{\mathrm{p}}$ & $k_{\varepsilon}$ & $x$ \\
\hline CMCCCMCC & 1.1 & 0.61 & -0.24 & -0.43 \\
\hline MCR & 2.3 & 0.69 & -0.20 & -0.35 \\
\hline CRC & 1.9 & 0.59 & -0.49 & -0.38 \\
\hline PM & 1.0 & 0.38 & -0.46 & -0.48
\end{tabular}

CMCC: Colloidal microcrystalline cellulose, MCR: Cellulose-based direct compression tableting excipient, CRC: Regenerated cellulose, PM: Powder metallurgy, AUC: Area under the curve

Table 4. \% Change in some physicochemical properties of tablets compressed with the named excipients and lubricated with different concentrations of MS

\begin{tabular}{|c|c|c|c|c|c|c|c|c|c|}
\hline \multirow{4}{*}{$\begin{array}{l}\text { Excipient } \\
\text { used }\end{array}$} & \multicolumn{9}{|c|}{$\%$ Change in } \\
\hline & $\mathrm{H}$ & $\mathrm{F}$ & $\mathrm{Dt}$ & $\mathrm{H}$ & $\mathrm{F}$ & $\mathrm{Dt}$ & $\mathrm{H}$ & $\mathrm{F}$ & $\mathrm{Dt}$ \\
\hline & \multicolumn{9}{|c|}{ For tablets lubricated with $\%$ MS w/w } \\
\hline & 1 & & & 2 & & & 3 & & \\
\hline CMCC & -11 & 14 & 23 & -18 & 20 & 43 & -30 & 27 & 53 \\
\hline MCR & -9 & 16 & 27 & -14 & 19 & 33 & -33 & 29 & 47 \\
\hline CRC & -22 & 18 & 43 & -33 & 22 & 51 & -42 & 34 & 62 \\
\hline
\end{tabular}

CMCC: Colloidal microcrystalline cellulose, MCR: Cellulose-based direct compression tableting excipient, CRC: Regenerated cellulose, MS: Magnesium stearate

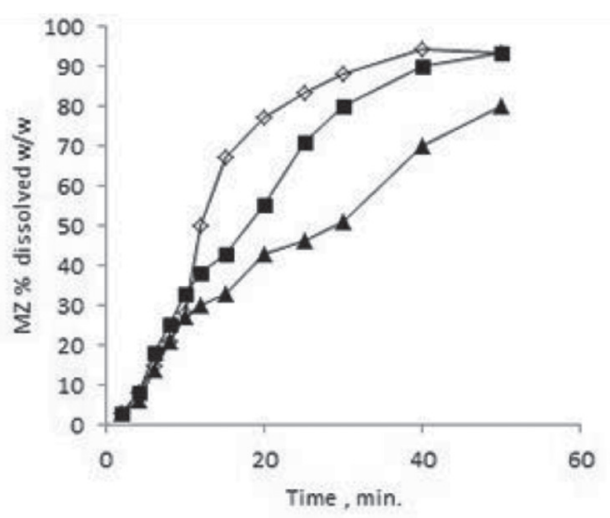

Figure 7. Dissolution profiles of $M Z$ tablets compressed from $\diamond, C R C$; $\square$, $M C R$; and $\triangle, C M C C$

MZ: Metronidazole, CRC: Regenerated cellulose, MCR: Cellulose-based direct compression tableting excipient, CMCC: Colloidal microcrystalline cellulose

in Figure 6 disclose that $k_{\varepsilon}$ and $x$ of a given excipient were functions of $k_{p}$ of the given excipient. In other words, the compressibility and the disintegration activity of an excipient are excipient compactibility dependent parameters. Figure 7 shows that tablets made from $\mathrm{CR}$ and MCR dissolved in more or less equal rates faster than those of the tablets made from CMCC.

\section{MCR sensitivity against MS}

Lubrication with MS generally produced less hard and more friable and slower disintegrating tablets. These adverse effects increased as the concentration of MS in a tested tablet batch increased. The changes in $\mathrm{H}, \mathrm{F}$, and $\mathrm{Dt}$ of tablets lubricated with $3 \% \mathrm{w} / \mathrm{w}$ MS are given in Table 4.

\section{DISCUSSION AND CONCLUSIONS}

The IR spectra in Figure 1 indicate that the tested powders are chemically similar. No new peaks suggesting the development of new materials were seen. The differences in the shape and intensity of the peaks were due to the different crystal lattices of the tested powders.

CMCC and CRC particles were elongated and amorphous. Such particles have a tendency to intermesh and create resistance (due to interparticle friction) to the flow of the bulk powder.12-15 This explains why CMCC is not a freely flowing powder $(0.21 \mathrm{~g}$ $\left.\mathrm{s}^{-1}\right)$. Although the Hausner ratio $(h)$ and the $\%$ compressibility determined for MCR were 1.6 and 38, MCR showed an improved flow rate. This is supported by the concept that the Hausner ratio and Carr's index, which are empirically derived parameters, failed in many cases to give a reliable base to judge powder flowability. The improved flow properties of MCR may be due to the glidant effect of CRC. It seems that CRC reduced the interparticle friction of the powder and improved its flow.

Since CRC had a large specific surface area wherein a large $\alpha$ is available, it is expected that MCR has improved compression and compaction properties and generates larger $A \cup C, k_{\varepsilon^{\prime}}$, and $k_{p}$ values. $\alpha$ of a given excipient may be calculated as;

$\alpha=L . k_{p} w t . \Sigma\left(r_{i} / M_{i}\right)$

where $L$, wt., $r_{i}$, and $M_{i}$ stand for Avogadro's number $\left(6.022 \times 10^{23}\right)$, the weight of the excipient in a batch, the fraction of a parent excipient used in coprocessing, and its molecular weight, respectively. CRC and MCR showed almost the same level of disintegration activity and they generated smaller $x$ values as shown in Table 3. CRC followed by MCR produced fast dissolving tablets. This is due to the powerful disintegration effect of CRC. ${ }^{15}$ Incorporating a powerful disintegrant in formulating tablets would contribute to the bioresponse of the tablets. MCR was unfortunately sensitive to MS.

In response to the increasing demand for inexpensive and multifunctional excipients with minimum risk to the products, MCR was engineered from MCC and regenerated cellulose. MCR has high functionality in terms of flow and compression, good binding properties, and strong disintegrating activity. However, it is sensitive to MS and exhibits high moisture uptake and therefore it is recommend as a complementary direct compression excipient.

\section{ACKNOWLEDGEMENT}

The author is grateful to Prof. Dr. J. Rojas for the technical assistance.

Conflict of Interest: No conflict of interest was declared by the authors. 


\section{REFERENCES}

1. Reimerdes D. The near future of tablet excipients. Manufacturing Chemist. 1993;64:14-15.

2. Saha S, Shahiwala AF. Multifunctional co-processed excipients for improved tabletting performance. Expert Opin Drug Deliv. 2009;6:197208.

3. Mirani AG, Patankar SP, Borole VS, Pawar AS, Kadam VJ. Direct compression high functionality excipient using co-processing technique: A brief review. Curr Drug Deliv. 2011;8:426-435.

4. Builders PF, Bonaventure AM, Tiwalade A, Okpako LC, Attama AA. Novel multifunctional pharmaceutical excipients derived from microcrystalline cellulose-starch microparticulate composites prepared by compatibilized reactive polymer blending. Int J Pharm. 2010;388:159-167.

5. Gonnissen Y, Remon JP, Vervaet C. Development of directly compressible powders via co-spray drying. Eur J Pharm Biopharm. 2007;67:220-226.

6. Gohel MC, Jogani PD. Exploration of melt granulation technique for the development of co-processed directly compressible adjuvant containing lactose and microcrystalline cellulose. Pharm Dev Technol. 2003;8:175185.

7. Sherwood BE, Becker JW. A New class of high functionality excipients: silicified microcrystalline cellulose. Pharm Technol. 1998;22:78-88.

8. Nachaegari SK, Bansal AK. Co-processed excipient for solid dosage forms. Pharm Techol. 2004;28:52-64.

9. York P. Crystal engineering and particle design for the powder compaction process. Drug Dev Ind Pharm. 1992;18:677-721.

10. Gohel MC, Jogani PD. A review of co-processed directly compressible excipients. J Pharm Pharm Sci. 2005;8:76-93.

11. Reier GE, Shangraw RF. Microcrystalline cellulose in tabletting. J Pharm Sci. 1966;55:10-15.

12. Zuurman K, Maarschalk VV, Bolhuis GK. Effect of magnesium stearate on bonding and porosity expansion of tablets produced from materials with different consolidation properties. Int J Pharm. 1999;179:107-115.

13. Kumar V. Powdered micro-fibrillated cellulose, US Patent 6,821,531 B2, 2004.
14. Ahmad FAS. Evaluation of regenerated cellulose as a glidant for Common Reed cellulose. IJPJ's J Pharm Cosmet. 2013;3:18-22.

15. Rojas J, López A, Gamboa Y, González C, Montoya F. Assessment of processing and polymorphic form effect on the powder and tableting properties of microcrystalline celluloses I and II. Chem Pharm Bull (Tokyo). 2011;59:603-607.

16. Aly SAS. Evaluation of Dis-Lub-Tout, a new co-processed tabletting excipient I. Physico-chemical properties. J Drug Del Sci Tech. 2014;24:503-506.

17. Aly SAS. Evaluation of Dis-Lub-Tout, a new co-processed tabletting excipient II. Lubricant property. J Drug Del Sci Tech. 2014;24:678-683.

18. Phillips MA, Samuel SL. Chemotherapy of protozoa infections. In: Brunton LL, Lazo JS, Parker KL, eds. The Pharmacological Basis of Therapeutics. 10th ed. New York; MCGraw-Hill Medical Publishing Division; 2006:10491069.

19. Chime SA, Onyishi VI, Onyechi JO. Co-processed metronidazole granules for tabletting: Formulation and in vitro evaluation. Int J Pharm Sci Rev. 2013;22:13-17

20. Adebowale BO, Oluwatomi O, Bakre L. Compressional properties of metronidazole tablet formulations containing aloe vera as binding agent. Int J Pharm Pharm Sci. 2014;10:261-264.

21. Rojas J, Lopez A, Guisao S, Ortiz C. Evaluation of several microcrystalline celluloses obtained from agricultural by-products. J Adv Pharm Technol Res. 2011;2:144-150.

22. Hu C, Liu Y. Quality Control in Pharmaceuticals: Residual Solvents Testing and Analysis. In: Akyar I, eds. Wide Spectra of Quality Control. INTECH; 2011 p.183-210. URL: http://www.intechopen.com/books/widespectra-of-quality-control.

23. Heckel RW. Density/pressure relationship in powder compaction. Trans Metall Soc AIME. 1961;22:1671-1675.

24. Antikainen O, Yliruusi J. Determining the compression behaviour of pharmaceutical powders from the force-distance compression profile. Inter J Pharm. 2003;61:253-261. 